\title{
Gut microbiota and metabolism
}

\author{
Nevin Ilhan
}

Department of Clinical Biochemistry, Fırat University, Elazığ, Turkey

\begin{abstract}
Objectives: The intestine of a healthy human harbors over 100 trillion cells that have a symbiotic relationship with the host, and they play a part in important metabolic, systemic, and immunologic functions. The human gut microbiota begins to take shape in the fetal life, and it achieves adult-like properties by the age of 2-3 years after being influenced by the type of delivery, feeding with either breast milk or formula, antibiotic use, as well as many environmental factors leading to dysbiosis. The important role that the gut microbiota plays in human metabolism and health, as well as identification of specific microorganisms that play role in various metabolic processes have encouraged researchers to investigate metabolism of dietary components and some metabolites produced by the host in particular. Important metabolic functions of the gut microbiota include fermentation of complex carbohydrates that escape digestion; various polyphenols consumed in the diet; fats, amino acids, and proteins; deconjugation of bile acids; and synthesis of vitamin $\mathrm{K}$ and several components of vitamin $\mathrm{B}$. This review aims to discuss the relationship between gut microbiota and metabolism of biochemically important macromolecules, flavonoids, and gases. In addition, a summary of the upto-date information on this subject is presented with the aim of emphasizing the importance of microbiota.
\end{abstract}

Keywords: Energy metabolism, gut microbiota, microbiome

$\mathrm{T}^{\mathrm{s}}$ he entire microorganisms (bacteria, viruses, fungi, archaea, and micro-eukaryotes) that are localized to a certain body region and live in a commensal relationship with humans are called microbiota, and the total genomes of all the microorganisms in a microbiota is called microbiome. The human microbiota genome is 150 times greater than the human genome, and the number of cells in the microbiota is 10 times greater than the number of human cells $\left(10^{14}\right)[1,2]$. The surface area of bacteria living in human body is $400 \mathrm{m2}$, and their mass is about $1.5-2 \mathrm{~kg}$ [3]. The Human Microbiome Project (HMP) focuses on using the approaches of metagenomics to examine the bacterial components of microbiota living in human body, as well as the distribution of microorganisms constituting the microbiota, and factors influencing their evolution [4]. The HMP studies have so far documented microbiome-related targets for human nutrition requirements, production, consumption, and distribution of nutrients, and they also revealed that the characteristics of microbial population localized to five appropriate regions of human body (gut, mouth, airways, uro- genital area, and skin) are quite distinct. These variations are influenced by many endogenous and exogenous factors that change within the lifetime, including host genetics [5], delivery type, nutritional state [6], lifestyle, antibiotic use, diseases [7], geographical area of residence, and bacteria types $[8,9]$. For instance, while Proteobacteria (e.g. Escherichia or Shigella) colonize newborns at birth, members of the phylum Actinobacteria (e.g. Bifidobacteriaceae) increase after several days from birth [10]. At 2 months of age, there are abundant levels of Enterobacteriaceae, Bifidobacteriaceae, and Clostridiaceae, whereas these show a consistent decrease by the age of 18 months [11]. From infancy to elderly period, Firmicutes bacteria increases, while Bacteriodetes decreases. Moreover, antibiotic use causes transient or permanent microbial dysbiosis depending on the type and the age at which they are used [9]. Metagenomic studies have revealed the existence of a common functional core microbiome despite inter-individual variations in a population $[12,13]$. A great portion of the human microbiota colonize all exposed surfaces of the body (skin,

Address for correspondence: Nevin Ilhan, MD. Department of Clinical Biochemistry, Fırat University, Elazığ, Turkey Phone: +90 42423700 00/46 97 E-mail: drnilhan@yahoo.com ORCID: 0000-0002-0208-8929

Accepted Date: August 16, 2018 Available Online Date: August 16, 2018 Available Online Date: September 25, 2018

${ }^{\circ}$ Copyright 2018 by International Journal of Medical Biochemistry - Available online at www.internationalbiochemistry.com 
genitourinary system, respiratory system) and even placenta and amniotic fluid during pregnancy. Contrary to the belief that the fetus exists in a sterile/aseptic environment. and colonization starts just after birth, demonstration of the presence of bacteria in placenta [14], umbilical cord blood [15], amniotic fluid, and meconium [16] of healthy newborns suggests that microbial colonization starts in fetal life, plays important role in healthy development of immunological and metabolic development, and is a progress that continues throughout the whole life of an individual. It is continuously shaped by various factors including the type of delivery (vaginal/Caesarian section), breastfeeding versus formula-feeding, antibiotic/ probiotic use, and environmental factors. By 2 years of age, the child's microbiota diversity and composition becomes similar with the microbiota found in an adult gastrointestinal system [17]. During birth, the newborn microbiota comes into contact with the microorganisms in the vaginal canal, and the first food that influences the microbiota is the breast milk. Breast milk contains prebiotics (oligosaccharides, lysosomes, lactoferrin, antibodies, and cytokines) and probiotics (Bifidobacterium, Lactobacillus) at the same time. Breastfed infants were shown to have increased number of Bifidobacterium (90\%) in their gut and lower levels of Lactococcus compared to formula-fed infants. That means, the bacterial growth favors Actinobacteria and Firmicutes in breastfed infants, but favors Actinobacteria and Bacteroides in formula-fed infants $[18,19]$. During the transition to supplementary nutrients, it is believed that selection of proper food increases bacterial diversity and shapes microbiota in a favorable way [20]. Delivery type is another very important factor influencing the microbiota that the baby will have. For example, Caesarian section results in lesser number of Bifidobacterium and Bacteroides species in comparison to normal vaginal delivery [21].

Intestinal microbiota is like a fingerprint; it has unique composition, diversity, and functional qualities. In healthy humans, Firmicutes (Gram-positive microorganisms producing butyrate, such as Ruminococcus, Clostridium, Eubacterium, Butyrivibrio, Anaerostipes, Roseburia, Faecalibacterium, etc.) and Bacteroidetes (Gram-negative microorganisms responsible for degradation of many complex glycans, such as Bacteroides, Porphyromonas, Prevotella, etc.) dominate the gut microbiota (90\%), whereas Proteobacteria (Gram-negative species like Escherichia and Enterobacteriaceae), Actinobacteria (Grampositive, the genus Bifidobacterium that is commonly used as probiotic), Fusobacteria and Verrucomicrobia (includes microbes responsible of mucosal damage, such as Akkermansia) species are the minor components of gut microbiota [22, 23]. This complex community of microorganisms interact with each other as well as the host, and comprises bacteria that are beneficial or harmful to some extent. They act as a 'metabolic organ' by interacting with the energy metabolism, metabolism of dietary components, intestinal epithelial cells, and by modulating host's nutrition, physiological, metabolic, and immune systems as well as host's behavior, motor system, and endocrine functions. Indeed, in qualitative and quantitative terms, the metabolic activity of the gut microbiota resembles that of an organ [24]. Furthermore, various molecular, cellular, and metabolic components of the gut microbiota are continuously in interaction with our organs, and this influences our health. Therefore, it is not surprising that the intestinal microbiota is referred to as the forgotten organ [25]. Due to the highly complicated and complex relationship, there is a dynamic balance between the gut microbiota and the host, which plays a key role in maintaining intestinal homeostasis. In the gut microbiota, many different bacterial populations live together in certain proportions in a steady state, and the diversity of this population is an indicator of healthy state [26]. When certain species start to dominate and suppress others, a pathological condition ensues (decreasing diversity). Any change caused by environmental factors, lifestyle, disease state, or infections results in alteration of the composition of bacterial populations, and thus, it disturbs the balance in microbiota. This is known as dysbiosis [27]. Microbial dysbiosis results in a disturbance in the ratio of beneficial/harmful bacteria, and it has been associated with various diseases including inflammatory bowel disease (IBD), metabolic syndrome, and colorectal cancer. Transferring gut microbiota of diseased animals to germfree or susceptible mice has resulted in similar pathologies in the recipient donors [28-30]. This suggests that any possible manipulations to the intestinal microbiota might be used as therapeutic modalities to prevent and/or treat some diseases. Gut microbiota is also important in the systemic immune response due to the great number of microorganisms. The gut microbiota mediates this immune response primarily by producing metabolic products (interleukin (IL)-1, IL-18, interferons, tumor necrosis factor (TNF), IL-10, serum amyloid A) and microbial associated molecular patterns (MAMPs) [31]. Increasing intestinal barrier resistance and protecting mucosal tissues from antigens and pathogens are among the mechanisms that have been defined for microbiota-mediated modulation of epithelial immunity. For example, short chain fatty acids (SCFA) that are produced by microbiota through fermentation have direct effects on regulatory T cells (Treg) by regulating their growth and functions, and trigger production of IL-18, which has protective effect for enterocytes [32]. Also, IL-22 that is produced in the lymphoid tissue through mediation of signal transducer and transcription activators 3 (STAT3) boosts intestinal barrier resistance and protects from bacterial and proinflammatory factors [33]. Additionally, myeloid differentiation factor 88 (MyD88) that is expressed in the intestines increases epithelial cell immunoglobulin A $(\lg A)$ secretion. In addition, bacterial flagellin activates toll-like receptor 4 in the dendritic cells, and it promotes differentiation of B-lymphocytes toward IgA-producing cells. IgA binds to microbial antigens, neutralizes pathogenic activity, and prevents infections. On the other hand, commensal bacteria stimulate pro-IL-1 $\beta$ production from host macrophages and modulate innate immunity of the host, and they induce expression of endothelial adhesion molecules that contribute in breakdown of intestinal pathogens and neutrophil recruitment. The NKT 
cells, which are a subset of T cells expressing both T-cell receptor and natural killer cell receptor, promote inflammation by releasing the cytokines IL-2, IL-4, IL-13, IL-17A, IL-21, TNF, and interferon-y (IFN-y). Protection of these cells' homeostasis prevents exaggerated inflammatory reaction [34]. The direct encounter between microbiota and the hematopoietic cells because of dysbiosis or disruption of the intestinal barrier initiates the inflammatory response. Although microbiota is the densest at bowels, its effect on host's immunity extends beyond the gastrointestinal system. These interactions with the immune system result in different outcomes with actions of various microbial structures and metabolites. A better understanding of the dynamic relationship between microbiota and the host at genetic and epigenetic levels as well as advances in '-omics' technologies (metagenomics, immunogenomics) helps us to comprehend the relationship between microbiota and the immune response, which has been described as a love-hate relationship [35].

The signaling that occurs between microbiota components and the immune system as well as development of new strategies for re-establishing or resetting the disturbed communication networks are the result of the association of development of various immune pathologies with the disturbed relation between microbiota and the host. In addition to energy cultivation and storage, microbiota plays an effective role in various metabolic functions including fermentation and absorption of undigested carbohydrates, maturation and functioning of immune cells through interaction with the immune system, and brain growth and behavioral regulation [36].

\section{Gut microbiota and carbohydrate metabolism}

Gut microbiota derives its nutrients from dietary components and shedding epithelial cells of the host. It is a standalone organ with its capacity for comprehensive metabolic functions and important functional plasticity. The part of the diet that reaches the large intestines is mostly made of complex polysaccharides that contain bonds resistant to digestive enzymes. In addition to the indigestible polysaccharides, a wide diversity of complex glycans, monosaccharides, and disaccharides that are not completely absorbed in the upper GIS due to excess consumption or incomplete digestion, and some endogenous substrates are available for the colonic microbiota metabolism [37]. In some individuals, complex polysaccharides except weakly fermented cellulose and undigested lignin are diffusely degraded in the large intestine, and they are fermented by the gut microbiota. Fermentation of carbohydrates that escaped proximal digestion and of undigested oligosaccharides by colonic organisms like Bacteroides (resistant starch, xylan), Roseburia (resistant starch, xylan, and oligosaccharides), Ruminococcus (resistant starch, cellulose), Bifidobacterium (oligosaccharides), Fecalibacterium, and Enterobacteria result in synthesis of SCFAs that are rich energy source for the host (acetate, propionate, butyrate; in molar ratios varying between 3: 1: 1 and 10: 2: 1), and of various metabolites. SCFAs like acetate, propionate, and butyrate regu- late intestinal immune homeostasis, and they serve as an energy source for the colonic epithelium. SCFAs increase the activity of phosphorylated AMP-activated protein kinase (AMPK) in liver and muscle. AMPK is a key enzyme regulating the cellular energy and reduced fat and glycogen stores by increasing energy expenditure and beta-oxidation of fatty acids. Moreover, SCFAs play role in glucose and energy homeostasis by modulating levels of several intestinal hormones including the glucagon-like peptide (GLP)-1 and ghrelin [38, 39]. Additionally, the gut microbiota alters peripheral fat storage by regulating the epithelial expression of the fasting-induced adipocyte factor (FIAF, angiopoietin-like 4 protein, ANGPTL4 or peroxisome proliferator active receptor- $\gamma$ (PPAR- $\gamma$ ) angiopoietin-related PGAR), which functions as a lipoprotein lipase (LPL) inhibitor in circulation. FIAF produced by brown and white adipose tissues, liver, and intestines inhibit LPL that regulates fatty acid oxidation in both muscle and fat tissue. LPL promotes fatty acid release from circulating chylomicrons and VLDL, and this leads to triglyceride storage in the adipose tissue. Inhibition of LPL by FIAF leads to reduced fat deposition [40]. SCFAs absorbed from the intestines are important signaling molecules of satiety that have potent effects on energy expenditure and insulin sensitivity in the peripheral metabolic tissues by interacting with the intestinal fatty acid receptors GPR41 and GPR43 (G protein-linked receptor), also known as FFAR2 and FFAR3, which are capable of activating the intestinal gluconeogenesis (IGN) [41, 42]. Among SCFAs, acetate primarily binds with GPR43, propionate with GPR41 and GPR43, and butyrate with GPR41. The receptors GPR41 and GPR43 are expressed in the intestinal epithelium [43]. SCFAs increase expression of PPARs that are important mediators of adipogenesis. Through binding to GPR41, SCFAs stimulate leptin expression by adipocytes. Binding with GPR43 is thought to stimulate adipogenesis. Thus, the resulting fatty acid profile might be associated with development of obesity (34). Nonetheless, more studies are needed to confirm these findings in humans. Butyrate, which is undeniably the most important SCFA for human health, is a principle energy source for human colonocytes, and it has potential anti-cancer activity with its ability to regulate gene expression through induction of apoptosis in colon cancer cells and inhibition of histone deacetylases [44]. The benefits of butyrate on glucose and energy homeostasis involve its ability to activate IGN through a cAMP-dependent mechanism [41]. Butyrate is formed by condensation of two molecules of acetyl-CoA followed by reduction to butyril-CoA. Butyril-CoA can be converted to butyrate via actions of phosphotransbutyrilase and butyrate kinase [45]. Butyrl-CoA can also be converted to butyrates via butyrl-CoA: acetate CoA-transferase pathway [46]. Some gut microorganisms can use both lactate and acetate to synthesize butyrate that prevents lactate accumulation and stabilizes the intestinal environment. Propionate is an energy source for epithelial cells, and it plays role in gluconeogenesis after being transferred to the liver [47]. Conversion of propionate to glucose in intestinal gluconeogenesis directly pro- 
motes energy homeostasis by reducing hepatic glucose production, and as a result, reduces adiposity [41]. Propionate is produced in the succinate pathway where succinate is converted to methylmalonyl-CoA. Propionate is synthesized from acrylate via propandiol pathway, in which lactate, a precursor of acrylate pathway [48], and deoxyhexose sugars (like fructose and ramnose) act as substrates [49]. Acetate is the most abundant SCFA, and it is a cofactor/metabolite necessary for growth of other bacteria. Acetate is produced by many intestinal bacteria from pyruvate via acetyl-CoA or Wood-Ljungdahl pathway. Acetate is carried to peripheral tissues of human body, and it is used in cholesterol metabolism and lipogenesis. Recent evidence has shown that acetate plays important role in central appetite control $[50,51]$. While acetate is produced by many bacteria from metabolites, propionate and butyrate are only produced by some certain species (Bacteroidetes and Firmicutes) through fermentation of peptides and amino acids [50,52]. In vitro studies have shown that aspartate, alanine, threonine, and methionine are the main sources of propionate, whereas butyrate is primarily produced via fermentation of glutamate, lysine, histidine, cysteine, serine, and methionine. Bacteria also produce intermediate fermentation products such as fumarate, succinate, and lactate; however, these are found in low levels in feces samples from healthy individuals as they are utilized extensively. On the other hand, significantly higher levels of lactate found in patients with ulcerative colitis might probably be an indicator for the disease [53]. SCFAs that form because of fermentation of carbohydrates by intestinal microbiota initiate various metabolic activities (like lipid and glucose synthesis), and they provide additional calories that is as much as nearly $10 \%$ of the daily production. SCFAs are believed to contribute to this energy balance by activating two kinds of G-protein-linked receptors (GPR41 and GPR43). The resulting SCFAs also influence intestinal environment; for example, intestinal $\mathrm{pH}$ is decreases due to the great amount of acids formed. Low pH can affect local growth of enteropathogens, but it can also modify metabolite absorption by colonocytes. Butyrate is metabolized locally by colonocytes, whereas acetate and propionate enter circulation and are transferred to liver for gluconeogenesis, and to heart or brain for oxidation, respectively. Acetate can pass the blood-brain barrier, and it might reduce appetite via a central homeostatic mechanism [51]. Despite their low peripheral concentrations, propionate and butyrate have indirect effects on peripheral organs via hormonal or nervous system activation [54, 55]. Along with other molecules that influence intestinal motility, SCFAs regulate food transit by fibers and contribute in epithelial cell proliferation [56]. This interaction triggers secretion of peptide tyrosine tyrosine/ pancreatic peptide YY3-36 (PYY), which is a hormone that suppresses intestinal movements and delays intestinal transit. Acetate induces epithelial expression of anti-microbial peptide LL37 [57], and it senses GPR41 and GPR43 in intestinal immune cells and regulates inflammation [58]. Activation of GPR41 leads to increased leptin levels and reduced neuropep- tide $Y$ levels, increased glucagon-like peptide (GLP)-1, whereas activation of GPR43 leads to increased adipogenesis through propionate and acetate [59]. In humans, acute administration of insulin-propionate, which can be metabolized by the microbiota to produce propionate in colon, reduced the calorie intake from a meal while causing significant increases in postprandial GLP-1 and PYY. Additionally, long-term administration resulted in a marked decrease in weight gain [60]. Human studies have demonstrated increased plasma PYY and GLP-1 concentrations with rectal and intravenous acetate perfusion [61], and propionate administration in healthy women for a 7-week period was shown to reduce fasting glucose levels and increase insulin release during oral glucose tolerance test [62]. This suggests presence of an association between SCFAs and enteroendocrine hormones and glucose homeostasis. Oral acetate gavage in obese and diabetic rats was shown to increase weight gain and glucose tolerance [63], and improved glucose homeostasis was found in rodents receiving propionate or butyrate supplementation [41, 64]. Mice fed with high-fat diet enriched with butyrate were shown to have increased thermogenesis and energy expenditure, and they developed resistance against obesity [65]. Butyrate prevents accumulation of toxic metabolites such as D-lactate, and it modulates immune cell function and migration [66]. Disturbance in the ability of colonocytes to utilize SCFAs as an energy source may contribute in development of IBDs such as ulcerative colitis. Butyrate infusion in such patients results in improvement in distal colitis symptoms [67]. This effect of butyrate has been documented in experimental animal models showing effectiveness of resistant starch and prebiotics (fructans and galacto-oligosaccharides) as reduced severity of the induced colitis $[68,69]$. One study suggested that GOSs can modulate immune response in humans, and reported that GOS supplementation showed effects on composition of intestinal microbiota by increasing Bifidobacterium populations, resulted in significant increase in fecal secretory lgA, decrease in fecal calprotectin and plasma C-reactive protein, decrease in the levels of markers of metabolic syndrome including blood insulin, total cholesterol, and total cholesterol/high-density lipoprotein ratio [70]. Since most of the saccharolytic activity takes place in the ascending colon, the SCFA concentrations are higher in this part of the colon. Increased luminal SCFA concentrations can be achieved by introducing non-dietary starch polysaccharides and resistant starch into the diet. SCFA is associated with cell proliferation and a decrease in apoptosis of colon carcinoma cell lines [71]. Reduced SCFA concentration throughout the length of the colon is correlated with increasing prevalence of benign and malignant tumors of the distal colon. Beneficial effects in fermentation and colon physiology were observed with increasing consumption of resistant starch (prebiotic) and non-starch polysaccharides (NSP, main components of dietary fiber) in the diet, and this finding supported the opinion about their protective effect against colorectal cancer [72]. Oxalate synthesized in intestines because of carbohydrate fermentation and bacterial metabolism 


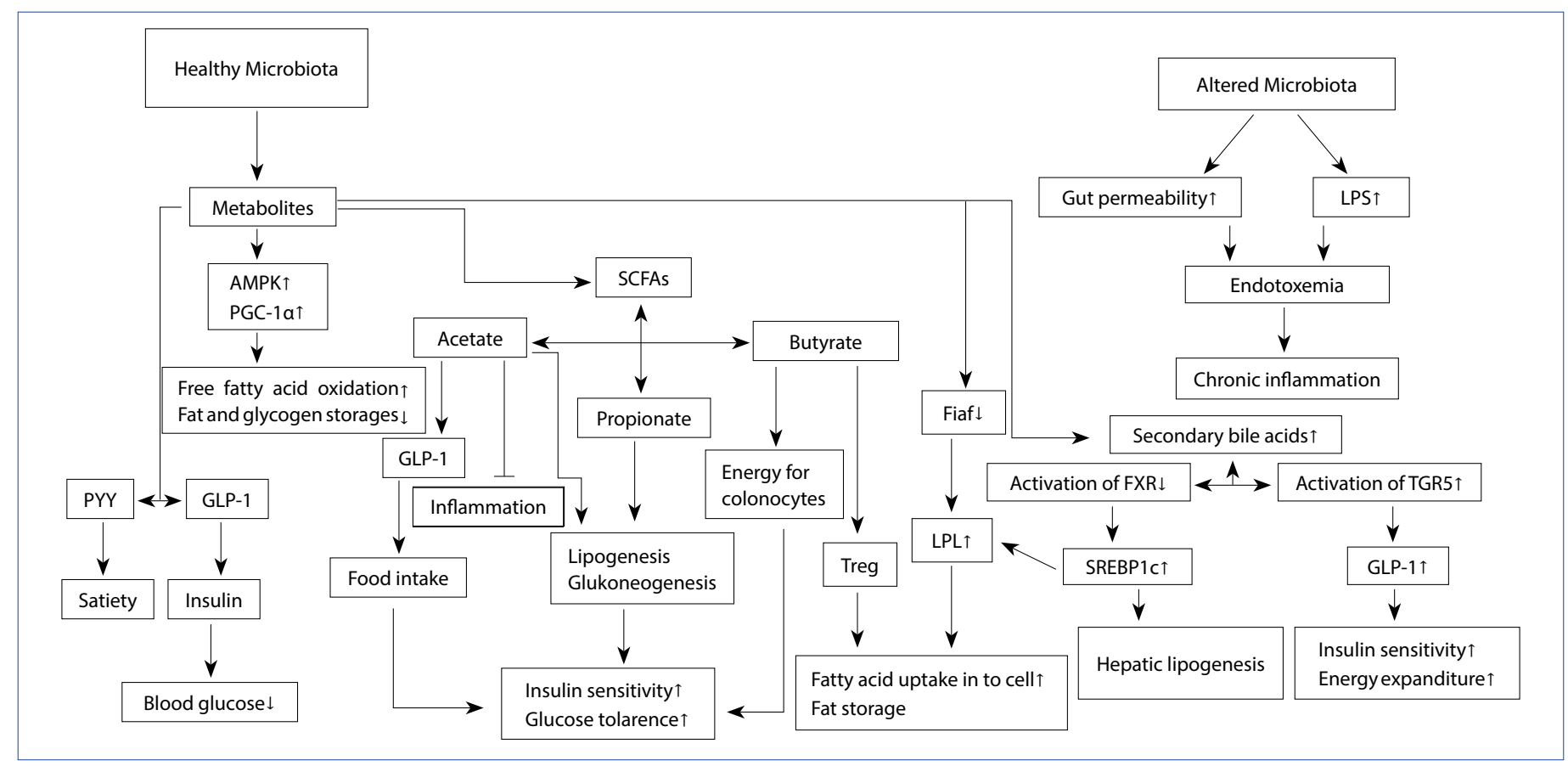

Figure 1. Regulation of host metabolism and immunity by gut microbiota. Gut microbiota metabolize indigestible dietary polysaccharides into SCFAs (acetate, propionate, and butyrate), affecting host metabolism and immunity. Microbial metabolites from this process improve host metabolism. In particular, the secretion of peptide hormones, such as PYY and GLP-1, is promoted by microbial metabolites: PYY decreases appetite, increases gut mobility, and GLP-1 lowers blood glucose level via promotion of insulin secretion. Among SCFAs, acetate and propionate activate lipogenesis and gluconeogenesis, and improve insulin sensitivity and glucose tolerance. Acetate also promotes secretion of ghrelin, a hunger hormone, and increases food intake. Butyrate is an essential energy source for colonocytes, and it has anti-inflammatory function like acetate. Butyrate enhances gut barrier function of intestinal epithelial cells and increases regulatory $\mathrm{T}$ (Treg) cells. In addition, gut microbiota suppress expression of fasting-induced adipose factor (Fiaf), an inhibitor of LPL, promoting fat storage in adipocytes. Bile acids can influence energy expenditure and glucose homeostasis by activating bile acid receptors and triggering downstream signaling pathways, for example, via their effects on gluconeogenesis, glycogenolysis, insulin secretion, and insulin sensitivity. These receptors include the ligandactivated nuclear receptors such as the farnesoid-X-receptor (FXR) as well as the cell surface located G-protein-coupled bile acid receptor TGR5. The increase in secondary bile acids could lead to increased TGR5 activation, thereby affecting glucose homeostasis via GLP-1, PYY and/or modulation of energy expenditure in peripheral tissues. Diet, drug administration, and disease states affect the intestinal microbiome, leading to transient or persistent dysbiosis, depending on the nature of the insult and its duration. Dysbiosis of the gut microbiome has also been shown to damage the permeability of the intestinal barrier, thus allowing bacterial components such as LPS to permeate the gut lining, activate TLR signaling and stimulate endotoxemia-induced metabolic inflammation. SCFAs, short-chain fatty acids; PYY, peptide YY; GLP-1, glucagon-like peptide-1; LPL, lipoprotein lipase; SREBP1, sterol response element binging protein 1

is inhibited by microorganisms like Oxalobacter formigenes, Lactobacillus spp., and Bifidobacterium spp., and thus the risk of oxalate stone formation in the kidneys is reduced. Fructose is a short-chain carbohydrate that can be transported into the small intestines, but it has the lowest absorption rate. Non-absorbable sugar alcohols that are widely used in food products (e.g. sorbitol, mannitol, glycerol) can be fermented by lactic acid bacteria, as well as $\gamma$-Proteobacteria species that includes Escherichia coli and Salmonella [73]. An in vitro fermentation study showed that a high-energy fructose-enriched medium was strongly butyrogenic [74]. Furthermore, fructans are known to promote butyrate production in the human intestine by bacterial cross-feeding or by stimulating the growth of butyrate-producing bacteria $[75,76]$. Lactate, which is produced by lactic acid bacteria by utilizing fructose and sugar alcohols, is fermented by the butyrate-producing bacteria to metabolize butyrate and consequently to contribute in the intestinal energy metabolism [77]. In addition, the resulting increase in dietary energy extraction and metabolism can promote metabolic disturbances [73]. Various other bacterial metabolites produced by human intestinal microbiota have effect on intestinal health. SCFAs produced in the intestine because of the saccharolytic activity enter portal circulation after being absorbed in the intestines [78].

\section{Gut microbiota and the lipid metabolism}

Unabsorbed and non-metabolized fatty acids are utilized by colonocytes as energy source or by liver for gluconeogenesis. Obese mice have been shown to produce much more SCFA due to microbiota's influence on the lipid metabolism. It has been proposed that microbiota influences lipid metabolism in both serum and liver through various ways. An increase in 
fat tissue LPL leads to increased cellular intake of fatty acids. Gut microbiota suppresses expression of lipoprotein lipase inhibitor in adipose tissue cells, and thus it has favorable effects on fatty acid reabsorption and lipid metabolism. Another pathway through which the microbiota allegedly influences lipid absorption is increased expression of several genes including carbohydrate response element binding protein, sterol response element binding protein 1 (SREBP1), acetyl CoA carboxylase (ACC1), and fatty acid synthase. The latter two of these are the rate-limiting enzymes of lipogenesis, which means that the resulting effect is increased fatty acid levels in the colonized germ free mice $[79,80]$. In addition, Bacteroides thetaiotaomicron has been shown to increase lipid hydrolysis by regulating the expression of colipase, which is necessary for pancreatic lipase in digestion of lipids [81]. High-fat diet leads to disruption of mucosal integrity and an increase in the plasma levels of lipopolysaccharide (LPS), the main component of the cell wall of Gram-negative bacteria. The increased LPS goes through translocation through intestinal capillaries via a mechanism involving TLR-4. The disturbance in the intestinal permeability stimulates systemic inflammation with high fat accumulation in liver, and increases in the blood levels of IL-1, IL-6, plasminogen activator inhibitor-1 (PAI-1), and TNF-a. AMPK that is activated by SCFAs synthesized by microbiota suppresses FIAF expression, and this in turn results in increased LPS activity and suppression of peroxismal proliferator-activated receptor co-activator (PGC)-1a that function in beta-oxidation. Accelerated development of metabolic diseases such as obesity and diabetes occurs because of suppression of PGC-1a, which regulates transcription factors playing role in glucose, lipid, and cholesterol metabolism, such as PPAR- $a$, PPAR- $\gamma$, PPAR- $\delta$, and farnesoid-X-receptor (FXR) [38]. (Fig. 1, 2).

\section{Gut microbiota and bile acid metabolism}

Diet rich in saturated fatty acids has been shown to contribute to development of steatosis and obesity, and increase Firmicutes/Bacteroidete ratio in intestinal microbiota. Conjugated linoleic acid (CLA) is produced by Bacteroides species via biohydrogenation of unsaturated fatty acid. CLA has anti-carcinogenic, anti-diabetic, anti-atherogenic, anti-obesogenic, hypolipidemic, and immunomodulatory properties. CLA tends to increase serum insulin and glucose levels in non-diabetic animals and humans, whereas it causes a decrease in serum insulin, glucose, and fatty acid levels in rats with diabetes [82]. Primary bile acids are synthesized in the liver via oxidation of cholesterol, whereas the gut microbiota deconjugates and dehydrates these bile acids in the human colon to form the secondary bile acids (deoxycholic and lithicholic acids). Major elimination route for the body cholesterol is through bile acids. Recent evidence has shown that bile acids not only are responsible for digestion of fat, emulsification of dietary fat, and absorption of lipids and lipophilic vitamins from the intestines [83] but also act as important signaling molecules with multiple physiological functions, contributing to cellu-

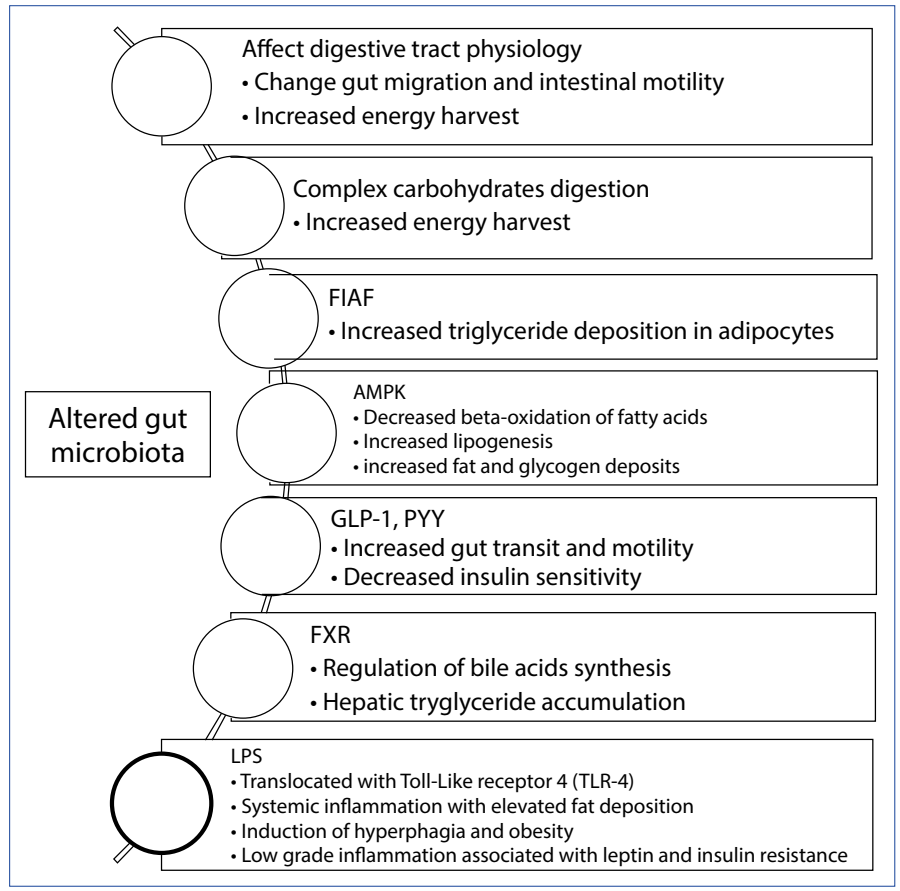

Figure 2. Metabolic interactions between gut microbes and the host in the metabolic diseases. The gut microbiota participates in the physiology and motility of the digestive tract and in the digestion of complex carbohydrates, influencing host energy harvest. The gut microbiota inhibits fasting-induced adipose factor (FIAF) in the intestine, and monophosphate activated protein kinase (AMPK) in several organs such as the brain and muscle, which leads to an increase in fat accumulation. The short-chain fatty acids (SCFAs; acetate, propionate, and butyrate) are created by microbial fermentation of starches and fibers in the colon and moderately metabolized by gut epithelial cells, and then go into circulation to exert their systemic effects (energy metabolism, regulation of immune responses, gut motility, and blood pressure) through the G-protein-coupled receptors (GPR41 and GPR43). Luminal acetate or propionate sensed by GPR41 and GPR43 releases PYY and GLP1 , affecting satiety and intestinal transit. The gut microbiota also contributes to fat deposition through the regulation of the farnesoid $X$ receptor (FXR), the bile acid receptor responsible for the regulation of bile acid synthesis and hepatic triglyceride accumulation. LPS is continuously produced by Gram-negative bacteria in the gut, and it is translocated through the intestinal capillaries by a mechanism involving toll-Like receptor 4 (TLR-4). Higher levels of circulating LPS initiate weight gain and contribute to a state of chronic low-grade inflammation

lar and metabolic activities by interacting with the bile acid receptors of the host $[84,85]$, and to development of insulin resistance and diabetes with their hormone-like effects. Several important signaling pathways including the nuclear bile acid receptors, FXR, pregnane $X$ receptor, androstan receptor, vitamin $D$ receptor, and cell surface activated G-protein-linked bile acid receptor-1 (GPBAR-1, also known as TGR5) have been found to be the targets for bile acids [85]. Bile acids show different affinities for these receptors, and they regulate their own 
homeostasis via different signaling pathways. Secondary bile acids metabolized by the microbiota bind to TGR5 receptor group with higher affinity than primary bile acids. TGR5 is expressed with high rates in liver, intestine, brown fat, and immune cells. TGR5 plays role in regulation of multiple metabolic functions including energy and glucose homeostasis [86]. Activation of TGR5 receptor by bile acids and synthetic agonists protects intestinal barrier function, reduces inflammation, and it stimulates filling of gallbladder and GLP-1 release from enteroendocrine L-cells. GLP-1 secretion is stimulated by the food inside the intestinal lumen, such as carbohydrates, fats, and proteins, and the glucose-induced GLP-1 secretion is increased with bile acids [87]. GLP-1 stimulates insulin synthesis, increased postprandial insulin secretion from pancreatic $\beta$ cells, inhibits glucagon release, and increases insulin resistance [88]. Activation of TGR5 increases intracellular CAMP by stimulating CAMP-dependent protein kinase $A$, which activates $C A M P$ responsive element binding protein, thyroid hormone deiodinase 2 (Dio2), and white fat tissue to brown fat tissue conversion factors, and this causes regression in obesity and hepatic steatosis in diet-induced obese mice by stimulating white fat tissue energy metabolism $[86,88]$. Recently, TGR5 has been shown to play important role in bile acid synthesis and hunger-induced hepatic steatosis in mice [89], to increase sensitivity to insulin and glucose by stimulating TGR5 expression and GLP-1 release through activation of FXR by agents that bind bile acids and prevent them from entering enterohepatic circulation, and to improve metabolic disorder symptoms [90]. FXR signaling pathway protects bile acid homeostasis by regulating both enterohepatic circulation and the bile acid biosynthesis, and also improves hepatic steatosis by regulating lipogenesis gene expression [91]. FXR activation reduces gluconeogenesis by downregulating the gene expressions of gluconeogenesis enzymes phosphoenolpyruvate kinase, glucose-6-phosphatase, and fructose-1,6 biphosphatase [92] (Fig. 2).

\section{Gut microbiota and protein/amino acid metabolism}

Proteins are initially digested by pancreatic enzymes and enterocytes released from intestines. Most of oligopeptides and amino acids enter portal system through the transporters located on the enterocytes in small intestines, and only $10 \%$ of proteins reach colon. Unlike enterocytes in small intestines, colonocytes do not absorb proteins, and the proteins that reach the colon are fermented and converted to various metabolites by the bacterial microbiota [93]. Amino acids are among the major macronutrients in diet. They are not only structural units for proteins and peptides but also necessary for synthesis of various bioactive molecules that function in regulation of signaling pathways and metabolism in the body $[94,95]$. Pieces of evidence from recent comprehensive studies have revealed that gut bacteria play important roles in metabolism and recycling of amino acids and other nitrogen compounds. Gut bacteria or microbiota either use nutrients or amino acids (AA) from host as building blocks for protein synthesis, or convert these nutrient to produce metabolites like ammonia, hydrogen sulfide, nitric oxide, polyamines, phenolic and indolic compounds in small and large intestines, or metabolize these through fermentation [96]. In addition, gut bacteria can synthesize part of the essential AA that can contribute to the regulation of AA homeostasis in the body, and this indicates the significance of amino acid metabolism by intestinal microbiota over the host nutrition and physiology [97]. Gut microbiota has significant proteolytic power together with human proteinases, owing to the effectiveness of microbial proteinases and peptidases, and proteins are hydrolyzed to peptides and AA by the action of these enzymes [98]. The liberated peptides and AA are available for use by bacteria and the host. Different amino acid transporters located on the bacterial cell wall facilitate amino acid entry into the bacteria from the intestinal lumen; here, several gene products convert AA to small signaling molecules and anti-microbial peptides (bacteriocins). Examples are conversion of L-histidine to histamine by the bacterial enzyme histamine decarboxylase that is encoded by bacterial hdcA genes, and conversion of glutamate to $\gamma$-amino butyric acid (GABA) by glutamate decarboxylases that are encoded by bacterial gadB genes. However, some bacteria cannot utilize extracellular AA due to deficiency of certain transporters. Recent studies have shown that many bacteria including Prevotella ruminicola, Butyrivibrio fibrisolvens, Megasphaera elsdenii, Mitsuokella multiacidas, Selenomonas ruminantium, and Streptococcus bovis have abundant active dipeptidyl peptidase and dipeptidase. Evidence suggests that these bacteria might be important for protein digestion and AA absorption in the mammalian digestive tract [93].

Theoretically, gut bacteria are capable of catabolizing almost all sorts of AAs. However, glutamine/glutamate, asparagine/ aspartate, lysine, arginine, glycine, and leucine, valine and isoleucine among the branched chain AAs are the AA substrates preferred by the colonic bacteria [96]. Main routes for microbial AA catabolism are deamination and decarboxylation. Bacterial fermentation products of AAs include ammonia, SCFAs (acetate, propionate, and butyrate), branched chain fatty acids (BCFAs, valerate, Isobutyrate, and isovalerate), gases $\left(\mathrm{H}_{2^{\prime}} \mathrm{CO}_{2^{\prime}} \mathrm{CH}_{4^{\prime}}\right.$ and $\mathrm{H}_{2} \mathrm{~S}$ ), aromatic compounds (phenol, p-cresol, indole), polyamines (agmatine, putrescine, spermidine, cadaverine), organic acids (lactate, formate, succinate, and oxaloacetate), phenolic and indolic compounds (phenylalanine and tryptophane metabolites), ethanol, and compounds with potential neuroactive effects (GABA, serotonin, histamine, LDOPA, triamin, nitric oxide, tryptamine, phenethylamine) [93]. These bacterial metabolites influence epithelial physiology by controlling signaling pathways in epithelial cells and modulating host's immune system [99]. They also modulate bacterial gene expression that leads to production of enzymes functioning in the AA metabolism [100]. Furthermore, many of the formed metabolites have toxic properties. Anaerobic degradation (the process which is also called as putrefaction) of undigested or endogenous proteins that are not digested by microbiota in the colon is generally regarded as harmful 
for host's health. For that reason, these metabolites that result from high-protein diet are claimed to be responsible for various chronic and inflammatory diseases (colorectal cancer, IBD, and atherosclerosis) [101, 102]. In vitro studies using isolated colonocytes or cell lines have confirmed the toxicity potential of protein fermentation metabolites such as $\mathrm{NH} 3$ and $\mathrm{H}_{2} \mathrm{~S}$ [103]. The most convincing evidence about the potential harmful effects of protein fermentation came from animal studies. The association between high-protein intake and colorectal cancer risk has been attributed to induction of genetic damage in colonocytes in some studies; however, human epidemiological studies do not support this association. Moreover, some studies have even demonstrated the protective effect of protein from non-red meat sources $[104,102]$. One mechanism by which protein-rich diet accelerates atherosclerosis is elevation of trimethylamine-N-oxide (TMAO) levels. In humans, TMAO is a metabolite produced in liver from trimethylamine (TMA) that is produced in intestines. Food precursors containing TMA residue such as choline, phasphatidylcholine, L-carnitine, $y$ butyrobetaine, and betaine are metabolized by microbiota to TMA. These reactions are catalyzed by choline TMA-lyase that is encoded by Clostridium XIVa strains and Eubacterium spp., and carnitine oxygenease that originates from $\gamma$-Proteobacteria found in human fecal samples. TMA that is produced in the intestine is then absorbed to the portal circulation, and is converted to TMAO by flavin monooxygenase 3 (FMO3) in liver. High plasma TMAO levels have been associated with cardiovascular disease, atherosclerosis, inflammation, and increased platelet activity [105-107]. The association between TMAO and atherosclerosis has been documented by demonstrating increased macrophage foam cell formation in arterial walls and peritoneal space of ApoE -/- mice that were fed with a diet fortified with choline and TMAO [108]. Similarly, protein levels of scavenger receptors (CD36 and SR-A1) that play role in cholesterol accumulation on macrophages and formation of foam cells were found to be elevated by diet rich in TMAO-, choline-, or L-carnitine. These dietary exposures, along with differences in bile acid pool size and composition, result in alteration in sterol metabolic pathway in tissues including arterial wall, liver, and intestines $[108,109]$. On the other hand, TMAO has been shown to activate inflammatory pathways. TMAO can induce inflammatory proteins such as IL-6, CPX-2, E-selectin, and ICAM-1 in particular. While increasing the macrophage adhesion, TMAO can prevent wound healing responses via PKC and NF-KB signals $[110,111]$. In humans, the TMAO precursors such as choline and L-carnitine have been found to be closely associated with downregulated levels of TMAO, which is considered as an indicator of altered gut microbiota [109, 112]. Zhu et al. studied the association between diet and microbiota in arterial thrombosis, and found that gut microbiota can directly alter ADP- and thrombin-dependent platelet hypersensitivity, platelet aggregation, adhesion of platelet to collagen, and clot formation rate by producing TMAO [113]. Therefore, the hypothesis stating that inhibition of metaorganismal TMAO pathway could be beneficial in humans for prevention of ath- erosclerosis and atherothrombosis should be tested in preclinical studies to create grounds for future clinical studies.

\section{Gut microbiota and vitamin metabolism}

It has been known for nearly half a century now from the findings of studies with germfree, conventional rats and volunteering humans that intestinal microbiota can synthesize certain vitamins including vitamin $\mathrm{K}$, biotin, and $\mathrm{B}$ group of vitamins like cobalamin, folate, nicotinic acid, and pantothenic acid [114]. These vitamins are highly important for bacterial metabolism. For example, germfree rats raised without vitamin $\mathrm{K}$ in their diet show low levels of prothrombin and develop hemorrhages, while conventionally raised rats show normal prothrombin levels and normal coagulation activity [115]. Although humans fed with low vitamin $\mathrm{K}$ diet for 3-4 weeks develop no vitamin deficiency. Suppression of intestinal microbiota with wide spectrum antibiotics results in significant reduction in plasma prothrombin levels [116]. Recently, metagenomics sequencing has been utilized to gather information about the vitamin synthesis pathways of intestinal microbiota. One study that systematically examined the genomes of 256 common gut bacteria with regard to biosynthetic pathways of eight $B$ vitamins (biotin, cobalamin, folate, niacin, pantothenate, pyridoxine, riboflavin, and thiamin) has reported the phylum rates including potential producers of each vitamin [117]. Recent research has shown that human intestinal microbiota contributes to degradation of various polyphenols (phenolic compounds consumed in diet). Most polyphenols are weakly absorbed from the small intestines, and they pass to the colon [118]. Secondary polyphenolic compounds such as flavanols, flavanones, flavan-3-ols, anthocyanidins, isoflavones, flavones, tannins, stilbenes, lignans, and chlorogenic acids are found as glycosides (conjugated with sugars like glucose, galactose, ramnose, ribulose, arabinopyrinose, and arabinofuranose) in various plants, fruits, and foods of plant origin (tea, cocoa, wine). The inactive polyphenols in the diet are converted to active compounds after elimination of the sugar residue by intestinal microbiota [119]. Structural specificity of polyphenols as well as individual diversity of the microbiota determine the level of biotransformation occurring in the intestine. Active end products are absorbed from the portal vein, and upon reaching tissues and organs, these products exhibit anti-microbial and other metabolic activities. One example to this metabolic activity is the conversion of inactive isoflavones to aglycones that have anti-androgenic and hypolipidemic properties [120]. In addition to their inherent anti-microbial activities, flavonoids can also increase the amount of certain bacteria in the intestines. This stimulatory effect of flavonoids on bacteria depends on both the structure and dosage of specific flavonoids, and the microbial species and strains as well [121]. Flavonoid-induced alteration of the composition of microbiota may have several health effects related to various processes regulated by microbiota. Flavonoids modulate microbial populations by producing endotoxins, converting primary bile acids to secondary bile acids that play important 
roles in both health and disease states $[122,86]$, influencing epigenetic changes [123], contributing to maintenance of immune homeostasis [124], and contributing to absorption and metabolism of nutrients and bioactive molecules including formation of SCFAs [125]. The relationship between flavonoids and microbiota is bidirectional. While flavonoids inhibit or promote growth of certain microorganisms, microorganisms metabolize flavonoids. Apart from the parent organism, these metabolites might influence the host and/or other microorganisms as well. Except for flavonols, majority of flavonoids are present as O- or C-glycosides, and they are generally subjected to deglycosylation prior to absorption or additional conversion. Since human enzymes cannot hydrolyze C-glycosides, humans are dependent on bacteria to break down C-glycosides [126]. Flavonoid glysosides, aglycones, and phenolic acid metabolites differ in terms of their biological activities. For instance, 3.4-dihydroxyphenylacetic acid and 4-hydroxyphenylacetic acid, which are metabolites of phenolic acid, show greater anti-platelet aggregation activity (a measure related to anti-cardiovascular disease properties of flavonoids) than flavonoid glycosides and derived aglycones show [127]. Metabolism of flavonoids may also alter their anti-proliferative activities against cancer cells; for example, in vitro studies have shown that they do not inhibit routine cancer cell proliferation but are hydrolyzed by the microbial enzyme hesperidinase, and show moderate anti-proliferative activity against selected cell lines [128]. The ability of flavonoids to shape microbiome presentations may be exploited as promising diet-based treatment approach to various dysbiosis-related conditions. For example, it has been shown that polyphenols from orange and apple can alter microbiome in patients with systemic lupus erythematous, flavanones can increase levels of Lactobacillus and dihydroflavonols can increase Bifidobacterium. This suggests that systemic lupus erythematous-associated dysbiosis can be corrected through dietary changes focusing on flavonoids [129].

\section{Gut microbiota and gases}

Gas production is the inevitable result of microbial fermentation in anaerobic systems including the digestive tract. However, it is not ubiquitous to all anaerobic bacteria, and some species have been found to not produce gas. This is true for common probiotics such as Lactobacilli and Bifidobacteria. Theoretically, use of probiotics and prebiotics can reduce gas formation in intestines, and can help to avoid malodor. Gas formation because of anaerobic bacterial fermentation can be eliminated in part via lungs and flatus. Studies on healthy humans have shown that the amount of gas disposal via flatus can reach several liters per day. Majority of the gas produced by bacteria is made of hydrogen, carbon dioxide, and methane [130]. The hydrogen composition of flatus can reach up to $40 \%$, and this is solely of microbial in origin.

Hydrogen $\left(\mathrm{H}_{2}\right)$ is produced by various gut bacteria including Bacteroides and Clostridium species in particular. These are the main members of microbiota, and this indicated that they are the principle source of microbial gas. Hydrogen can be reused by gut microbiota, and the amount of production is theoretically much more than the disposed amount. $\mathrm{H}_{2}$ is one of the principle regulators of organic material degradation, and its elimination allows greater oxidation of organic substrates, and therefore, greater energy efficiency through anaerobic fermentation. Its accumulation can prevent further organic material oxidation in a negative feedback loop, depending on the partial pressure of $\mathrm{H}_{2}$ in intestine. For that reason, $\mathrm{H}_{2}$ is principally consumed by hydrogenotropic microbes and converted to other metabolites such as methane (methanogens), acetate (hydrogenotropic acetogens), or hydrogen sulfide (sulfate-reducing bacteria). Therefore, $\mathrm{H}_{2}$ metabolism of gut microbiota is key to effective intestinal fermentation $[130,131]$.

$4 \mathrm{H}_{2}+\mathrm{SO}_{4}{ }^{2-}+\mathrm{H}^{+} \rightarrow \rightarrow \mathrm{HS}^{-}+4 \mathrm{H}_{2} \mathrm{O}$

Carbon dioxide $\left(\mathrm{CO}_{2}\right)$ is another quantitatively important gas disposed with flatus. The total expelled amount (stomach, intestines, etc.) can be $5 \%-50 \%$ of the gas volume, and it is recycled with hydrogen through methanogenesis, and to a lesser extent, through acetogenesis.

$4 \mathrm{H}_{2}+\mathrm{CO}_{2} \rightarrow \mathrm{CH}_{4}+2 \mathrm{H}_{2} \mathrm{O} \rightarrow \rightarrow \rightarrow \rightarrow 4 \mathrm{H}_{2}+\mathrm{CO}_{2} \rightarrow \mathrm{CH}_{3} \mathrm{COOH}+2 \mathrm{H}_{2} \mathrm{O}$

Unlike hydrogen and methane, $\mathrm{CO}_{2}$ is produced not only with bacterial metabolism but also as a result of diffusion from blood to colon lumen, acidification of bicarbonate in upper gastrointestinal tract, and during bacterial metabolism as well $[130,132]$. Some Clostridia species (e.g. C.sporogenes, C.butyricum, and C.perfringens) produce both $\mathrm{CO}_{2}$ and $\mathrm{H}_{2}$ in their metabolic pathways. Gas production by colonic microbiota might have clinical consequences for the host. For example, one common feature of inflammatory bowel syndrome is excessive gas production and belching associated with flatulence and abdominal distention. Lack of bacterial hydrogen recycling can lead to pneumatosis cystoides intestinalis that is characterized by excess gas production and presence of gasfilled cysts in the colon wall [133].

\section{Conclusion}

Gut microbiota is composed of trillions of bacteria that normally live in a balance. Gut microbiota is especially affected by nutrition, genetic, and environmental factors, and it is regarded as another organ of the body. It acts as a potential modulator of human physiology and biochemical pathways, and the strong reciprocal interaction between gut microbiota and nutrition sheds light on pathophysiology of various metabolic diseases. Nutrition regulates gut microbiota composition and function by influencing microbial diversity, intestinal barrier permeability, immune functions, energy harvest, macromolecule metabolism, and enzyme activities. Evidence from existing studies emphasize the importance of adequate and balanced nutrition with regard to energy and macronutrient components for gut microbiota. Further studies are necessary to clearly understand the mechanism of interactions between microbiota and macromolecules. 
Conflict of interest: There is no conflict of interest in this study.

\section{References}

1. Grice EA, Segre JA. The human microbiome: our second genome. Annu Rev Genomics Hum Genet 2012;13:151-70.

2. Haynes M, Rohwer F. The human virome. In: Nelson KE, editor. Metagenomics of the Human Body. New York: Springer; 2011. p. 63-78. [CrossRef]

3. Thursby $E$, Juge N. Introduction to the human gut microbiota. Biochem J 2017;474:1823-36. [CrossRef]

4. NIH HMP Working Group, Peterson J, Garges S, Giovanni M, Mclnnes P, Wang L, Schloss JA, et al. The NIH Human Microbiome Project. Genome Res 2009;19:2317-23. [CrossRef]

5. Goodrich JK, Waters JL, Poole AC, Sutter JL, Koren O, Blekhman $\mathrm{R}$, et al. Human genetics shape the gut microbiome. Cell 2014;159:789-99. [CrossRef]

6. Reinhardt C, Reigstad CS, Bäckhed F. Intestinal microbiota during infancy and its implications for obesity. J Pediatr Gastroenterol Nutr 2009;48:249-56. [CrossRef]

7. Schroeder BO, Bäckhed F. Signals from the gut microbiota to distant organs in physiology and disease. Nat Med 2016;22:1079-89. [CrossRef]

8. Goodrich JK, Davenport ER, Waters JL, Clark AG, Ley RE. Crossspecies comparisons of host genetic associations with the microbiome. Science 2016;352:532-5. [CrossRef]

9. Zhang C, Zhang M, Wang S, Han R, Cao Y, Hua W, et al. Interactions between gut microbiota, host genetics and diet relevant to development of metabolic syndromes in mice. ISME J 2010;4:232-41. [CrossRef]

10. Bäckhed F, Roswall J, Peng Y, Feng Q, Jia H, KovatchevaDatchary $P$, et al. Dynamics and Stabilization of the Human Gut Microbiome during the First Year of Life. Cell Host Microbe 2015;17:690-703. [CrossRef]

11. Yassour $M$, Vatanen $T$, Siljander $H$, Hämäläinen $A M$, Härkönen T, Ryhänen SJ, et al. Natural history of the infant gut microbiome and impact of antibiotic treatment on bacterial strain diversity and stability. Sci Transl Med 2016;8:343ra81. [CrossRef]

12. Gensollen T, lyer SS, Kasper DL, Blumberg RS. How colonization by microbiota in early life shapes the immune system. Science 2016;352:539-44. [CrossRef]

13. Chung H, Pamp SJ, Hill JA, Surana NK, Edelman SM, Troy EB, et al. Gut immune maturation depends on colonization with a host-specific microbiota. Cell 2012;149:1578-93. [CrossRef]

14. Aagaard K, Ma J, Antony KM, Ganu R, Petrosino J, Versalovic J. The placenta harbors a unique microbiome. Sci Transl Med 2014;6:237ra65. [CrossRef]

15. Jiménez $E$, Fernández L, Marín ML, Martín R, Odriozola JM, Nueno-Palop $C$, et al. Isolation of commensal bacteria from umbilical cord blood of healthy neonates born by cesarean section. Curr Microbiol 2005;51:270-4. [CrossRef]

16. DiGiulio DB. Diversity of microbes in amniotic fluid. Semin Fetal Neonatal Med 2012;17:2-11. [CrossRef]

17. Rodríguez JM, Murphy K, Stanton C, Ross RP, Kober Ol, Juge $\mathrm{N}$, et al. The composition of the gut microbiota throughout life, with an emphasis on early life. Microb Ecol Health Dis 2015;26:26050.

18. Ballard O, Morrow AL. Human milk composition: nutrients and bioactive factors. Pediatr Clin North Am 2013;60:49-74.

19. Turroni F, Peano C, Pass DA, Foroni E, Severgnini M, Claesson $\mathrm{MJ}$, et al. Diversity of bifidobacteria within the infant gut microbiota. PLoS One 2012;7:e36957. [CrossRef]

20. Laursen MF, Bahl MI, Michaelsen KF, Licht TR. First Foods and Gut Microbes. Front Microbiol 2017;8:356. [CrossRef]

21. Marques TM, Wall R, Ross RP, Fitzgerald GF, Ryan CA, Stanton C. Programming infant gut microbiota: influence of dietary and environmental factors. Curr Opin Biotechnol 2010;21:149-56.

22. Eckburg PB, Bik EM, Bernstein CN, Purdom E, Dethlefsen L, Sargent $M$, et al. Diversity of the human intestinal microbial flora. Science 2005;308:1635-8. [CrossRef]

23. Sekirov I, Russell SL, Antunes LC, Finlay BB. Gut microbiota in health and disease. Physiol Rev 2010;90:859-904. [CrossRef]

24. Jandhyala SM, Talukdar R, Subramanyam C, Vuyyuru H, Sasikala M, Nageshwar Reddy D. Role of the normal gut microbiota. World J Gastroenterol 2015;21:8787-803. [CrossRef]

25. O'Hara AM, Shanahan F. The gut flora as a forgotten organ. EMBO Rep 2006;7:688-93. [CrossRef]

26. Faith JJ, Guruge JL, Charbonneau M, Subramanian S, Seedorf $H$, Goodman $A L$, et al. The long-term stability of the human gut microbiota. Science 2013;341:1237439. [CrossRef]

27. Carding S, Verbeke K, Vipond DT, Corfe BM, Owen LJ. Dysbiosis of the gut microbiota in disease. Microb Ecol Health Dis 2015;26:26191.

28. Vijay-Kumar M, Aitken JD, Carvalho FA, Cullender TC, Mwangi $\mathrm{S}$, Srinivasan $\mathrm{S}$, et al. Metabolic syndrome and altered gut microbiota in mice lacking Toll-like receptor 5. Science 2010;328:228-31. [CrossRef]

29. Kostic AD, Chun E, Robertson L, Glickman JN, Gallini CA, Michaud $M$, et al. Fusobacterium nucleatum potentiates intestinal tumorigenesis and modulates the tumor-immune microenvironment. Cell Host Microbe 2013;14:207-15. [CrossRef]

30. Shanahan F, Quigley EM. Manipulation of the microbiota for treatment of IBS and IBD-challenges and controversies. Gastroenterology 2014;146:1554-63. [CrossRef]

31. De Santis S, Cavalcanti E, Mastronardi M, Jirillo E, Chieppa M. Nutritional Keys for Intestinal Barrier Modulation. Front Immunol 2015;6:612. [CrossRef]

32. Smith PM, Howitt MR, Panikov N, Michaud M, Gallini CA, Bohlooly-Y $M$, et al. The microbial metabolites, short-chain fatty acids, regulate colonic Treg cell homeostasis. Science 2013;341:569-73. [CrossRef]

33. Kalina U, Koyama N, Hosoda T, Nuernberger H, Sato K, Hoelzer $D$, et al. Enhanced production of IL-18 in butyrate-treated intestinal epithelium by stimulation of the proximal promoter region. Eur J Immunol 2002;32:2635-43. [CrossRef]

34. Gomes AC, Hoffmann C, Mota JF. The human gut microbiota: Metabolism and perspective in obesity. Gut Microbes 2018:1-18. [CrossRef]

35. Tomkovich S, Jobin C. Microbiota and host immune responses: a love-hate relationship. Immunology 2016;147:1-10. [CrossRef] 
36. Burcelin R. Gut microbiota and immune crosstalk in metabolic disease. Mol Metab 2016;5:771-81. [CrossRef]

37. Macfarlane GT, Macfarlane S. Bacteria, colonic fermentation, and gastrointestinal health. J AOAC Int 2012;95:50-60.

38. Fluitman KS, De Clercq NC, Keijser BJF, Visser M, Nieuwdorp M, IJzerman RG. The intestinal microbiota, energy balance, and malnutrition: emphasis on the role of short-chain fatty acids. Expert Rev Endocrinol Metab 2017;12:215-26. [CrossRef]

39. Tolhurst G, Heffron H, Lam YS, Parker HE, Habib AM, Diakogiannaki $E$, et al. Short-chain fatty acids stimulate glucagonlike peptide-1 secretion via the G-protein-coupled receptor FFAR2. Diabetes 2012;61:364-71. [CrossRef]

40. Conterno L, Fava F, Viola R, Tuohy KM. Obesity and the gut microbiota: does up-regulating colonic fermentation protect against obesity and metabolic disease? Genes Nutr 2011;6:241-60. [CrossRef]

41. De Vadder F, Kovatcheva-Datchary P, Goncalves D, Vinera J, Zitoun C, Duchampt A, et al. Microbiota-generated metabolites promote metabolic benefits via gut-brain neural circuits. Cell 2014;156:84-96. [CrossRef]

42. Tazoe H, Otomo Y, Kaji I, Tanaka R, Karaki SI, Kuwahara A. Roles of short-chain fatty acids receptors, GPR41 and GPR43 on colonic functions. J Physiol Pharmacol 2008;59 Suppl 2:25162.

43. Lin HV, Frassetto A, Kowalik EJ Jr, Nawrocki AR, Lu MM, Kosinski JR, et al. Butyrate and propionate protect against diet-induced obesity and regulate gut hormones via free fatty acid receptor 3-independent mechanisms. PLoS One 2012;7:e35240. [CrossRef]

44. Steliou K, Boosalis MS, Perrine SP, Sangerman J, Faller DV. Butyrate histone deacetylase inhibitors. Biores Open Access 2012;1:192-8. [CrossRef]

45. Louis P, Duncan SH, McCrae SI, Millar J, Jackson MS, Flint HJ. Restricted distribution of the butyrate kinase pathway among butyrate-producing bacteria from the human colon. J Bacteriol 2004;186:2099-106. [CrossRef]

46. Duncan SH, Barcenilla A, Stewart CS, Pryde SE, Flint HJ. Acetate utilization and butyryl coenzyme A (CoA):acetate-CoA transferase in butyrate-producing bacteria from the human large intestine. Appl Environ Microbiol 2002;68:5186-90.

47. Brown AJ, Goldsworthy SM, Barnes AA, Eilert MM, Tcheang $L$, Daniels D, et al. The Orphan $G$ protein-coupled receptors GPR41 and GPR43 are activated by propionate and other short chain carboxylic acids. J Biol Chem 2003;278:11312-9.

48. Hetzel M, Brock M, Selmer T, Pierik AJ, Golding BT, Buckel W. Acryloyl-CoA reductase from Clostridium propionicum. An enzyme complex of propionyl-CoA dehydrogenase and electron-transferring flavoprotein. Eur J Biochem 2003;270:90210. [CrossRef]

49. Scott KP, Martin JC, Campbell G, Mayer CD, Flint HJ. Wholegenome transcription profiling reveals genes up-regulated by growth on fucose in the human gut bacterium "Roseburia inulinivorans". J Bacteriol 2006;188:4340-9. [CrossRef]

50. Ragsdale SW, Pierce E. Acetogenesis and the Wood-Ljungdahl pathway of $\mathrm{CO}(2)$ fixation. Biochim Biophys Acta
2008;1784:1873-98. [CrossRef]

51. Frost G, Sleeth ML, Sahuri-Arisoylu M, Lizarbe B, Cerdan S, Brody $L$, et al. The short-chain fatty acid acetate reduces appetite via a central homeostatic mechanism. Nat Commun 2014;5:3611. [CrossRef]

52. Louis P, Flint HJ. Formation of propionate and butyrate by the human colonic microbiota. Environ Microbiol 2017;19:29-41.

53. Bjerrum JT, Wang Y, Hao F, Coskun M, Ludwig C, Günther U, et al. Metabonomics of human fecal extracts characterize ulcerative colitis, Crohn's disease and healthy individuals. Metabolomics 2015;11:122-33. [CrossRef]

54. Koh A, De Vadder F, Kovatcheva-Datchary P, Bäckhed F. From Dietary Fiber to Host Physiology: Short-Chain Fatty Acids as Key Bacterial Metabolites. Cell 2016;165:1332-45. [CrossRef]

55. Marcobal A, Sonnenburg JL. Human milk oligosaccharide consumption by intestinal microbiota. Clin Microbiol Infect 2012;18 Suppl 4:12-5. [CrossRef]

56. Musso G, Gambino R, Cassader M. Interactions between gut microbiota and host metabolism predisposing to obesity and diabetes. Annu Rev Med 2011;62:361-80. [CrossRef]

57. Ashida H, Mimuro H, Ogawa M, Kobayashi T, Sanada T, Kim M, et al. Cell death and infection: a double-edged sword for host and pathogen survival. J Cell Biol 2011;195:931-42. [CrossRef]

58. Samuel BS, Shaito A, Motoike T, Rey FE, Backhed F, Manchester JK, et al. Effects of the gut microbiota on host adiposity are modulated by the short-chain fatty-acid binding $G$ protein-coupled receptor, Gpr41. Proc Natl Acad Sci U S A 2008;105:16767-72. [CrossRef]

59. Pluznick JL, Protzko RJ, Gevorgyan H, Peterlin Z, Sipos A, Han $J$, et al. Olfactory receptor responding to gut microbiotaderived signals plays a role in renin secretion and blood pressure regulation. Proc Natl Acad Sci U S A 2013;110:4410-5.

60. Chambers ES, Viardot A, Psichas A, Morrison DJ, Murphy KG, Zac-Varghese SE, et al. Effects of targeted delivery of propionate to the human colon on appetite regulation, body weight maintenance and adiposity in overweight adults. Gut 2015;64:1744-54. [CrossRef]

61. Freeland KR, Wolever TM. Acute effects of intravenous and rectal acetate on glucagon-like peptide-1, peptide YY, ghrelin, adiponectin and tumour necrosis factor-alpha. Br J Nutr 2010;103:460-6. [CrossRef]

62. Venter CS, Vorster HH, Cummings JH. Effects of dietary propionate on carbohydrate and lipid metabolism in healthy volunteers. Am J Gastroenterol 1990;85:549-53.

63. Yamashita H, Fujisawa K, Ito E, Idei S, Kawaguchi N, Kimoto M, et al. Improvement of obesity and glucose tolerance by acetate in Type 2 diabetic Otsuka Long-Evans Tokushima Fatty (OLETF) rats. Biosci Biotechnol Biochem 2007;71:1236-43.

64. Gao Z, Yin J, Zhang J, Ward RE, Martin RJ, Lefevre M, et al. Butyrate improves insulin sensitivity and increases energy expenditure in mice. Diabetes 2009;58:1509-17. [CrossRef]

65. Nicholson JK, Holmes E, Kinross J, Burcelin R, Gibson G, Jia $W$, et al. Host-gut microbiota metabolic interactions. Science 2012;336:1262-7. [CrossRef]

66. Walker AW, Duncan SH, McWilliam Leitch EC, Child MW, Flint 
$\mathrm{HJ} . \mathrm{pH}$ and peptide supply can radically alter bacterial populations and short-chain fatty acid ratios within microbial communities from the human colon. Appl Environ Microbiol 2005;71:3692-700. [CrossRef]

67. Bassaganya-Riera J, DiGuardo M, Viladomiu M, de Horna A, Sanchez S, Einerhand AW, et al. Soluble fibers and resistant starch ameliorate disease activity in interleukin-10-deficient mice with inflammatory bowel disease. J Nutr 2011;141:131825. [CrossRef]

68. Gopalakrishnan A, Clinthorne JF, Rondini EA, McCaskey SJ, Gurzell EA, Langohr IM, et al. Supplementation with galacto-oligosaccharides increases the percentage of NK cells and reduces colitis severity in Smad3-deficient mice. J Nutr 2012;142:1336-42. [CrossRef]

69. Vulevic J, Juric A, Tzortzis G, Gibson GR. A mixture of transgalactooligosaccharides reduces markers of metabolic syndrome and modulates the fecal microbiota and immune function of overweight adults. J Nutr 2013;143:324-31. [CrossRef]

70. Heerdt BG, Houston MA, Augenlicht LH. Potentiation by specific short-chain fatty acids of differentiation and apoptosis in human colonic carcinoma cell lines. Cancer Res 1994;54:3288-93.

71. Topping DL, Clifton PM. Short-chain fatty acids and human colonic function: roles of resistant starch and nonstarch polysaccharides. Physiol Rev 2001;81:1031-64. [CrossRef]

72. Payne AN, Chassard C, Lacroix C. Gut microbial adaptation to dietary consumption of fructose, artificial sweeteners and sugar alcohols: implications for host-microbe interactions contributing to obesity. Obes Rev 2012;13:799-809. [CrossRef]

73. Payne AN, Chassard C, Banz Y, Lacroix C. The composition and metabolic activity of child gut microbiota demonstrate differential adaptation to varied nutrient loads in an in vitro model of colonic fermentation. FEMS Microbiol Ecol 2012;80:60823. [CrossRef]

74. Belenguer A, Duncan SH, Calder AG, Holtrop G, Louis $P$, Lobley GE, et al. Two routes of metabolic cross-feeding between Bifidobacterium adolescentis and butyrate-producing anaerobes from the human gut. Appl Environ Microbiol 2006;72:3593-9. [CrossRef]

75. De Vuyst L, Leroy F. Cross-feeding between bifidobacteria and butyrate-producing colon bacteria explains bifdobacterial competitiveness, butyrate production, and gas production. Int J Food Microbiol 2011;149:73-80. [CrossRef]

76. Marquet P, Duncan SH, Chassard C, Bernalier-Donadille A, Flint $\mathrm{HJ}$. Lactate has the potential to promote hydrogen sulphide formation in the human colon. FEMS Microbiol Lett 2009;299:128-34. [CrossRef]

77. Fava F, Lovegrove JA, Gitau R, Jackson KG, Tuohy KM. The gut microbiota and lipid metabolism: implications for human health and coronary heart disease. Curr Med Chem 2006;13:3005-21. [CrossRef]

78. Bäckhed F, Crawford PA. Coordinated regulation of the metabolome and lipidome at the host-microbial interface. Biochim Biophys Acta 2010;1801:240-5. [CrossRef]

79. Delzenne NM, Williams CM. Prebiotics and lipid metabolism.
Curr Opin Lipidol 2002;13:61-7. [CrossRef]

80. Zocco MA, Ainora ME, Gasbarrini G, Gasbarrini A. Bacteroides thetaiotaomicron in the gut: molecular aspects of their interaction. Dig Liver Dis 2007;39:707-12. [CrossRef]

81. de Punder K, Pruimboom L. Stress induces endotoxemia and low-grade inflammation by increasing barrier permeability. Front Immunol 2015;6:223. [CrossRef]

82. Houseknecht KL, Vanden Heuvel JP, Moya-Camarena SY, Portocarrero $\mathrm{CP}$, Peck LW, Nickel KP, et al. Dietary conjugated linoleic acid normalizes impaired glucose tolerance in the Zucker diabetic fatty fa/fa rat. Biochem Biophys Res Commun 1998;244:678-82. [CrossRef]

83. Begley M, Sleator RD, Gahan CG, Hill C. Contribution of three bile-associated loci, bsh, pva, and bt|B, to gastrointestinal persistence and bile tolerance of Listeria monocytogenes. Infect Immun 2005;73:894-904. [CrossRef]

84. Li T, Chiang JY. Bile acid signaling in metabolic disease and drug therapy. Pharmacol Rev 2014;66:948-83. [CrossRef]

85. Vítek L, Haluzík M. The role of bile acids in metabolic regulation. J Endocrinol 2016;228:R85-96. [CrossRef]

86. Martinot E, Sèdes L, Baptissart M, Lobaccaro JM, Caira F, Beaudoin $C$, et al. Bile acids and their receptors. Mol Aspects Med 2017;56:2-9. [CrossRef]

87. Parker HE, Wallis K, le Roux CW, Wong KY, Reimann F, Gribble FM. Molecular mechanisms underlying bile acid-stimulated glucagon-like peptide-1 secretion. Br J Pharmacol 2012;165:414-23. [CrossRef]

88. Thomas C, Gioiello A, Noriega L, Strehle A, Oury J, Rizzo G, et al. TGR5-mediated bile acid sensing controls glucose homeostasis. Cell Metab 2009;10:167-77. [CrossRef]

89. Donepudi AC, Boehme S, Li F, Chiang JY. G-protein-coupled bile acid receptor plays a key role in bile acid metabolism and fasting-induced hepatic steatosis in mice. Hepatology 2017;65:813-27. [CrossRef]

90. Pathak P, Liu H, Boehme S, Xie C, Krausz KW, Gonzalez F, et al. Farnesoid $X$ receptor induces Takeda G-protein receptor 5 cross-talk to regulate bile acid synthesis and hepatic metabolism. J Biol Chem 2017;292:11055-69. [CrossRef]

91. Watanabe M, Houten SM, Wang L, Moschetta A, Mangelsdorf DJ, Heyman RA, et al. Bile acids lower triglyceride levels via a pathway involving FXR, SHP, and SREBP-1c. J Clin Invest 2004;113:1408-18. [CrossRef]

92. Ma K, Saha PK, Chan L, Moore DD. Farnesoid X receptor is essential for normal glucose homeostasis. J Clin Invest 2006;116:1102-9. [CrossRef]

93. Davila AM, Blachier F, Gotteland M, Andriamihaja M, Benetti $\mathrm{PH}$, Sanz $\mathrm{Y}$, et al. Re-print of "Intestinal luminal nitrogen metabolism: role of the gut microbiota and consequences for the host". Pharmacol Res 2013;69:114-26. [CrossRef]

94. Wu G. Functional amino acids in nutrition and health. Amino Acids 2013;45:407-11. [CrossRef]

95. Wu G, Bazer FW, Dai Z, Li D, Wang J, Wu Z. Amino acid nutrition in animals: protein synthesis and beyond. Annu Rev Anim Biosci 2014;2:387-417. [CrossRef]

96. Dai ZL, Wu G, Zhu WY. Amino acid metabolism in intestinal 
bacteria: links between gut ecology and host health. Front Biosci (Landmark Ed) 2011;16:1768-86. [CrossRef]

97. Metges CC. Contribution of microbial amino acids to amino acid homeostasis of the host. J Nutr 2000;130:1857S-64S.

98. Wallace RJ. Ruminal microbial metabolism of peptides and amino acids. J Nutr 1996;126:1326S-34S. [CrossRef]

99. Blachier F, Mariotti F, Huneau JF, Tomé D. Effects of amino acid-derived luminal metabolites on the colonic epithelium and physiopathological consequences. Amino Acids 2007;33:547-62. [CrossRef]

100. Bron PA, Grangette C, Mercenier A, de Vos WM, Kleerebezem $M$. Identification of Lactobacillus plantarum genes that are induced in the gastrointestinal tract of mice. J Bacteriol 2004; 186:5721-9. [CrossRef]

101. Davis CD, Milner JA. Gastrointestinal microflora, food components and colon cancer prevention. J Nutr Biochem 2009;20:743-52. [CrossRef]

102. Windey K, De Preter V, Verbeke K. Relevance of protein fermentation to gut health. Mol Nutr Food Res 2012;56:184-96.

103. Leschelle X, Robert V, Delpal S, Mouillé B, Mayeur C, Martel $\mathrm{P}$, et al. Isolation of pig colonic crypts for cytotoxic assay of luminal compounds: effects of hydrogen sulfide, ammonia, and deoxycholic acid. Cell Biol Toxicol 2002;18:193-203.

104. Toden S, Bird AR, Topping DL, Conlon MA. High red meat diets induce greater numbers of colonic DNA double-strand breaks than white meat in rats: attenuation by high-amylose maize starch. Carcinogenesis 2007;28:2355-62. [CrossRef]

105. Senthong V, Wang Z, Fan Y, Wu Y, Hazen SL, Tang WH. Trimethylamine N-Oxide and Mortality Risk in Patients With Peripheral Artery Disease. J Am Heart Assoc 2016;5. pii: e004237. [CrossRef]

106. Li XS, Obeid S, Klingenberg R, Gencer B, Mach F, Räber L, et al. Gut microbiota-dependent trimethylamine $\mathrm{N}$-oxide in acute coronary syndromes: a prognostic marker for incident cardiovascular events beyond traditional risk factors. Eur Heart J 2017;38:814-24. [CrossRef]

107. Rath S, Heidrich B, Pieper DH, Vital M. Uncovering the trimethylamine-producing bacteria of the human gut microbiota. Microbiome 2017;5:54. [CrossRef]

108. Wang Z, Klipfell E, Bennett BJ, Koeth R, Levison BS, Dugar $B$, et al. Gut flora metabolism of phosphatidylcholine promotes cardiovascular disease. Nature 2011;472:57-63.

109. Koeth RA, Wang Z, Levison BS, Buffa JA, Org E, Sheehy BT, et al. Intestinal microbiota metabolism of L-carnitine, a nutrient in red meat, promotes atherosclerosis. Nat Med 2013;19:576-85. [CrossRef]

110. Ma G, Pan B, Chen Y, Guo C, Zhao M, Zheng L, et al. Trimethylamine $\mathrm{N}$-oxide in atherogenesis: impairing endothelial selfrepair capacity and enhancing monocyte adhesion. Biosci Rep 2017;37. pii: BSR20160244. [CrossRef]

111. Seldin MM, Meng Y, Qi H, Zhu W, Wang Z, Hazen SL, et al. Trimethylamine N-Oxide Promotes Vascular Inflammation Through Signaling of Mitogen-Activated Protein Kinase and Nuclear Factor-KB. J Am Heart Assoc 2016;5. pii: e002767.

112. Wang Z, Tang WH, Buffa JA, Fu X, Britt EB, Koeth RA, et al.
Prognostic value of choline and betaine depends on intestinal microbiota-generated metabolite trimethylamine-N-oxide. Eur Heart J 2014;35:904-10. [CrossRef]

113. Zhu W, Gregory JC, Org E, Buffa JA, Gupta N, Wang Z, et al. Gut Microbial Metabolite TMAO Enhances Platelet Hyperreactivity and Thrombosis Risk. Cell 2016;165:111-24. [CrossRef]

114. Hill MJ. Intestinal flora and endogenous vitamin synthesis. Eur J Cancer Prev 1997;6 Suppl 1:S43-5. [CrossRef]

115. Gustafsson BE, Daft FS, Mcdaniel EG, Smith JC, Fitzgerald RJ. Effects of vitamin K-active compounds and intestinal microorganisms in vitamin K-deficient germfree rats. J Nutr 1962;78:461-8. [CrossRef]

116. Frick PG, Riedler G, Brögli H. Dose response and minimal daily requirement for vitamin $\mathrm{K}$ in man. J Appl Physiol 1967;23:387-9. [CrossRef]

117. Magnúsdóttir S, Ravcheev D, de Crécy-Lagard V, Thiele I. Systematic genome assessment of B-vitamin biosynthesis suggests co-operation among gut microbes. Front Genet 2015;6:148. [CrossRef]

118. Manach $C$, Scalbert $A$, Morand $C$, Rémésy $C$, Jiménez $L$. Polyphenols: food sources and bioavailability. Am J Clin Nutr 2004;79:727-47. [CrossRef]

119. Marín L, Miguélez EM, Villar CJ, Lombó F. Bioavailability of dietary polyphenols and gut microbiota metabolism: antimicrobial properties. Biomed Res Int 2015;2015:905215.

120. Landete JM, Arqués J, Medina M, Gaya P, de Las Rivas B, Muñoz R. Bioactivation of Phytoestrogens: Intestinal Bacteria and Health. Crit Rev Food Sci Nutr 2016;56:1826-43.

121. Gwiazdowska D, Juś K, Jasnowska-Małecka J, Kluczyńska K. The impact of polyphenols on Bifidobacterium growth. Acta Biochim Pol 2015;62:895-901. [CrossRef]

122. Long SL, Gahan CGM, Joyce SA. Interactions between gut bacteria and bile in health and disease. Mol Aspects Med 2017;56:54-65. [CrossRef]

123. Remely $M$, Haslberger AG. The microbial epigenome in metabolic syndrome. Mol Aspects Med 2017;54:71-7.

124. Maynard CL, Elson CO, Hatton RD, Weaver CT. Reciprocal interactions of the intestinal microbiota and immune system. Nature 2012;489:231-41. [CrossRef]

125. Shortt C, Hasselwander O, Meynier A, Nauta A, Fernández $E N$, Putz $P$, et al. Systematic review of the effects of the intestinal microbiota on selected nutrients and non-nutrients. Eur J Nutr 2018;57:25-49. [CrossRef]

126. Braune A, Blaut M. Bacterial species involved in the conversion of dietary flavonoids in the human gut. Gut Microbes 2016;7:216-34. [CrossRef]

127. Kim DH, Jung EA, Sohng IS, Han JA, Kim TH, Han MJ. Intestinal bacterial metabolism of flavonoids and its relation to some biological activities. Arch Pharm Res 1998;21:17-23.

128. de Araújo ME, Moreira Franco YE, Alberto TG, Sobreiro MA, Conrado MA, Priolli DG, et al. Enzymatic de-glycosylation of rutin improves its antioxidant and antiproliferative activities. Food Chem 2013;141:266-73. [CrossRef]

129. Cuervo A, Hevia A, López $P$, Suárez A, Sánchez B, Margolles $A$, et al. Association of polyphenols from oranges and ap- 
ples with specific intestinal microorganisms in systemic lupus erythematosus patients. Nutrients 2015;7:1301-17.

130. Rowland I, Gibson G, Heinken A, Scott K, Swann J, Thiele I, et al. Gut microbiota functions: metabolism of nutrients and other food components. Eur J Nutr 2018;57:1-24. [CrossRef]

131. Wolf PG, Biswas A, Morales SE, Greening C, Gaskins HR. $\mathrm{H}_{2}$ metabolism is widespread and diverse among human colonic microbes. Gut Microbes 2016;7:235-45. [CrossRef]

132. Suarez F, Furne J, Springfield J, Levitt M. Insights into human colonic physiology obtained from the study of flatus composition. Am J Physiol 1997;272:G1028-33.

133. Christl SU, Gibson GR, Murgatroyd PR, Scheppach W, Cummings $\mathrm{JH}$. Impaired hydrogen metabolism in pneumatosis cystoides intestinalis. Gastroenterology 1993;104:392-7. 